\title{
PHYSIOLOGICAL RESPONSES OF Eucalyptus camaldulensis (Dehnh.) TO SIMULATED GLYPHOSATE DRIFT
}

\author{
RESPOSTAS FISIOLÓGICAS DE Eucalyptus camaldulensis (DEHNH.) À DERIVA SIMULADA \\ DE GLIFOSATO
}

\author{
Diego Ariel Meloni ${ }^{1}$, Carlos Alberto Martínez ${ }^{2}$ \\ ${ }^{1}$ Universidad Nacional de Santiago del Estero, Facultad de Agronomía y Agroindustrias, Santiago del \\ Estero, Argentina-dmeloniunse@gmail.com \\ ${ }^{2}$ Department of Biology, FFCLRP, University of São Paulo, Ribeirão Preto, São Paulo, Brazil \\ carlosamhr@ffclrp.usp.br
}

\begin{abstract}
Weed control with glyphosate produces damages in plantations of Eucalyptus camaldulensis, although the involved physiological mechanisms have not been completely elucidated. This work aimed at assessing the physiological responses of $E$. camaldulensis to simulated glyphosate drift. Greenhouse trials were performed with four-month-old E. camaldulensis clone117 seedlings. The herbicide drift was simulated applying doses of $0 ; 43,2 ; 86,4 ; 172,8$ and $345,6 \mathrm{~g}$ a.e. ha ${ }^{-1}$ glyphosate. Twenty-three days after the application, we measured gas exchange and chlorophyll a fluorescence. We also quantified Rubisco activity and indicator variables of oxidative stress. Glyphosate decreased carbon photosynthetic assimilation, increased non-photochemical quenching, induced stomatal closure, and increased photoinhibition. It also decreased Rubisco activity and increased photorespiration. The herbicide produced oxidative stress, and increased the activities in the enzymes catalase, ascorbate peroxidase, and superoxide dismutase, involved in the detoxification of reactive oxygen species. We concluded that glyphosate's deleterious effects on the assimilation of $\mathrm{CO}_{2}$ in E. camaldulensis are due to stomatal and non-stomatal effects. The decrease in Rubisco activity, the increase in photorespiration, and photoinhibition stand out among non-stomatal effects. The increase in the activity of the antioxidant system is insufficient to compensate for the production of $\mathrm{H}_{2} \mathrm{O}_{2}$ in photorespiration, which damages the photosynthetic apparatus.
\end{abstract}

KEYWORDS: Antioxidant enzymes, Herbicides, Oxidative stress, Photosynthesis, Phytotoxicity.

\section{RESUMO}

O controle de plantas daninhas com glifosato produz danos em plantações de Eucalyptus camaldulensis, embora os mecanismos fisiológicos envolvidos não tenham sido completamente elucidados. Este trabalho teve como objetivo avaliar as respostas fisiológicas de E. camaldulensis à deriva simulada do glifosato. Os ensaios foram realizados em estufa, com mudas de $E$. camaldulensis clone117 de quatro meses. A deriva do herbicida foi simulada aplicando doses de $0 ; 43,2 ; 86,4 ; 172,8$ e $345,6 \mathrm{~g}$ a.e. ha ${ }^{-1}$ glifosato. Vinte e três dias após a aplicação foram medidas as trocas gasosas e a fluorescência da clorofila a. Também foram quantificadas a atividade da Rubisco e variáveis indicadoras de estresse oxidativo. O glifosato diminuiu a assimilação fotossintética do carbono, aumentou o quenching nãofotoquímico, induziu o fechamento estomático e aumentou a fotoinibição. Ele também diminuiu a atividade da Rubisco e aumentou a fotorrespiração. O herbicida produziu estresse oxidativo e aumentou as atividades das enzimas catalase, ascorbato peroxidase e superóxido dismutase, envolvidas na desintoxicação de espécies reativas de oxigênio. Conclui-se que os efeitos deletérios do glifosato na assimilação de $\mathrm{CO}_{2}$ em $E$. camaldulensis são devidos a efeitos estomáticos e não estomáticos. A diminuição da atividade da Rubisco, o aumento da fotorrespiração e fotoinibição destacam-se entre os efeitos não estomáticos. $O$ aumento da atividade do sistema antioxidante é insuficiente para compensar a produção de $\mathrm{H}_{2} \mathrm{O}_{2}$ na fotorrespiração, que danifica o aparato fotossintético.

PALAVRAS-CHAVE: Enzimas antioxidantes, Herbicidas, Estresse oxidative, Fotossíntese, Fitotoxicidade. 


\section{INTRODUCTION}

Eucalyptus plantations occupy approximately 20 million hectares worldwide and have great economic importance (CERVEIRA JUNIOR et al., 2020). During the first two years of establishment of eucalyptus plantations, weed control is a relevant practice (SANTOS JUNIOR et al., 2015). Glyphosate stands out among weed control methods; it is a non-selective broad-spectrum herbicide (TUFFI SANTOS et al., 2007). Its mechanism of action implies the inhibition of the enzyme 5enolpyruvylshikimate-3-phosphate synthase (EPSPS; EC 2.5.1.19), involved in the synthesis of aromatic amino acids (CRUZ et al., 2016). However, the herbicide drift is quite frequent; it reaches tree leaves producing some leaf death and reduced stand growth (TUFFI SANTOS et al., 2011). The physiological processes involved in these responses are not clear.

Although the mechanism of action of glyphosate is well known, a deficiency of aromatic amino acids was not observed after the application of the herbicide in some species, even though they presented the typical deleterious effects (SERRA et al., 2013). Therefore, glyphosate could affect other physiological processes. In some species, glyphosate inhibited photosynthesis with reported stomatal closure and a decrease in the concentration of photosynthetic pigments (GOMES et al., 2016).

Chlorophyll fluorescence analysis is a sensitive and non-destructive method that allows determining damage in the photosynthetic apparatus. It has been used to assess alterations in the photochemical stage of photosynthesis under different environmental stresses (SOUSA et al., 2014). Gomes et al. (2017) used this method to study the effect of glyphosate on photosynthesis in Salix miyabeana, proving that the herbicide decreases the potential quantum yield of Photosystem II (PSII). In Lupinus albus, glyphosate reduced $26 \%$ of the activity of the enzyme Ribulose $1,5-$ biphosphate carboxylase oxygenase (Rubisco), producing an important decrease in $\mathrm{CO}_{2}$ fixation (DE MARÍA et al., 2006).

Glyphosate might induce the accumulation of reactive oxygen species (ROS) that produces lipid peroxidation, cell membrane damage, and degradation of proteins and chlorophylls (MITEVA et al., 2010). It has been suggested that tolerance to glyphosate might be related to the capacity of activating antioxidant systems to detoxify such ROS (MAROLI et al., 2015).

This work aimed to evaluate the effects of different glyphosate doses on the physiological responses of Eucalyptus camaldulensis (Dehnh.). For this purpose, we hypothesized that, according to applied dose, glyphosate induces damages in the photochemistry of PSII by increasing photo-oxidative stress, decreasing the net assimilation rate.

\section{MATERIAL AND METHODS}

\section{Plant material and experimental approach}

All the tests were performed under greenhouse conditions in the experimental field of Universidad Nacional de Santiago del Estero $\left(27^{\circ} 45^{\prime} \mathrm{S}, 64^{\circ} 18^{\prime} \mathrm{W}\right)$, Argentina. Four-month-old E. camaldulensis clone 117 seedlings were used. The $40 \mathrm{~cm}$ tall seedlings were planted in $10 \mathrm{~L}$ pots containing loam soil. Pots were watered daily to keep the soil moisture close to the field capacity.

Doses of $0 ; 43,2 ; 86,4 ; 172,8$ and $345,6 \mathrm{~g}$ a.e. ha ${ }^{-1}$ glyphosate were applied, corresponding to $0,3,6,12$, and $24 \%$ of $1440 \mathrm{~g}$ a.e. ha ${ }^{-1}$ glyphosate potassium salt ( $\mathrm{N}$ phosphonomethyl glycine) produced by Monsanto Argentina under the trademark Roundup ${ }^{\circledR}$ Full II). The herbicide was applied so that it did not reach the upper third of the seedlings with a backpack sprayer equipped with a handheld boom consisting of two flat fan nozzles TT110.02, spaced 0,5 $\mathrm{m}$ apart, $250 \mathrm{kPa}$ pressure and water volume of $200 \mathrm{~L} \mathrm{ha}^{-1}$ (TUFFI SANTOS et al., 2007). During the application, the air temperature was $22{ }^{\circ} \mathrm{C}$ and the relative air humidity was $60 \%$.

The greenhouse presented the following environmental conditions: minimum temperature $16{ }^{\circ} \mathrm{C}$, maximum temperature $29{ }^{\circ} \mathrm{C}$, average relative air humidity $52 \%$, and maximum photosynthetic photon flux density (PPFD) $1500 \mu \mathrm{mol} \mathrm{m} \mathrm{m}^{-2} \mathrm{~s}^{-1}$.

Twenty-three days after the application of the herbicide, gas exchange and the chlorophyll a fluorescence were measured, and samples of leaves for chemical determinations were collected.

\section{Gas exchange and chlorophyll a fluorescence measurement}

Gas exchange and chlorophyll a fluorescence were measured using an infrared gas analyzer (IRGA LI 6400 XT, LICOR, USA) with an attached leaf chamber fluorometer (LI-6400-40, LICOR, USA). During measurements, the conditions inside the IRGA chamber were set to PPFD $1000 \mu \mathrm{mol} \mathrm{m}^{-2} \mathrm{~s}^{-1}, \mathrm{CO}_{2}$ partial pressure $38 \mathrm{~Pa}$, water vapor 
pressure deficit 1,2 $\pm 0,5 \mathrm{kPa}$, and average air temperature $25{ }^{\circ} \mathrm{C}$. The measurements were performed on the first leave completely expanded between 9:00 a.m. and 11:00 a.m.

Simultaneously with gas exchange measurements, chlorophyll a fluorescence was measured using the saturation pulse technique (SCHREIBER et al., 1994). Measurements were performed on dark-adapted leaves for $30 \mathrm{~min}$, and $F_{o}$ and $F_{m}$ (minimum and maximum fluorescence of dark-adapted leaves, respectively) values were registered. Subsequently, leaves were exposed to actinic light $\left(1000 \mu \mathrm{mol} \mathrm{m} \mathrm{m}^{-2}\right)$ for at least $30 \mathrm{~min}$. The intensity and length of saturation pulses were $8000 \mu \mathrm{mol}$ $\mathrm{m}^{-2} \mathrm{~s}^{-1}$ and $0,7 \mathrm{~s}$, respectively. Thus, the maximum quantum yield of PSII $\left(F_{v} / F_{m}\right)$ and the non-photochemical quenching (NPQ) were calculated according to Maxwell \& Johnson (2000). The photorespiration rate was calculated according to Valentini et al. (1995).

\section{Determination of membrane damage, lipid peroxidation and $\mathrm{H}_{2} \mathrm{O}_{2}$ concentration}

To estimate the damage to cell membranes, electrolyte leakage was measured using the technique proposed by Silva et al. (2019).

Lipid peroxidation was quantified through the formation of malondialdehyde (MDA) according to the technique described by Cakmak \& Horst (1991). An extinction coefficient of $155 \mathrm{mM}^{-1} \mathrm{~cm}^{-1}$ was used, and results were expressed as nmol $\mathrm{MDA} \mathrm{g}^{-1} \mathrm{FM}$.

The concentration of $\mathrm{H}_{2} \mathrm{O}_{2}$ was determined according to the technique described by Alexieva et al. (2001), and expressed in $\mu \mathrm{mol} \mathrm{g}^{-1} \mathrm{FM}$.

\section{Determination of enzymatic activities}

The total soluble proteins of leaves were extracted homogenizing $0,2 \mathrm{~g}$ of plant material in $100 \mathrm{mM} \mathrm{K}$ phosphate buffer, $\mathrm{pH} \mathrm{7,} \mathrm{containing} 1 \mathrm{mM}$ EDTA, and 1 $\mathrm{mM}$ ascorbate. The homogenate was centrifuged at $15000 \mathrm{~g}$ for $15 \mathrm{~min}$, and the obtained supernatant was used to perform enzymatic determinations. The concentration of total soluble proteins was quantified as described by Bradford (1976), using bovine serum albumin as standard.

Rubisco activity (EC 4.1.1.39) was measured with the method described by Reid et al. (1997), determining the oxidation rate of NADH at $340 \mathrm{~nm}$.

Catalase activity (CAT, E.C. 1.11.16) was determined according to the technique proposed by Havir \& McHale
(1987), following the oxidation of $\mathrm{H}_{2} \mathrm{O}_{2}$, at $240 \mathrm{~nm}$ and 30 ${ }^{\circ} \mathrm{C}$ and monitoring the absorbance over $300 \mathrm{~s}$. The activity was calculated using the molar extinction coefficient of $\mathrm{H}_{2} \mathrm{O}_{2}\left(36 \mathrm{M}^{-1} \mathrm{~cm}^{-1}\right)$.

Ascorbate peroxidase activity (APX, E.C. 1.11.1.11) was determined following ascorbate oxidation (NAKANO \& ASADA 1981).

Superoxide dismutase activity (SOD, E.C. 1.15.1.1) was determined from the inhibition of the blue formazane production, by the nitro blue tetrazolium photoreduction (GIANNOPOLITIS \& RIES, 1977).

\section{Experimental design and statistical analysis}

The experiments were arranged in a completely randomized design with 10 replicates. The experimental unit consisted of a pot containing a eucalyptus seedling. Results were analyzed with ANOVA and Tukey's test $(P<$ 0.05).

\section{RESULTS AND DISCUSSION}

Photosynthetic carbon assimilation $(A)$ was very sensitive to glyphosate; we detected a decrease of 20$80 \%$ in plants treated with 43,2 and $345,6 \mathrm{~g}$ a.e. ha ${ }^{-1}$ glyphosate, respectively, against control (Figure 1A). In contrast, stomatal conductance $\left(g_{s}\right)$ was not affected by 43,2 g a.e. ha ${ }^{-1}$ glyphosate (Figure $1 \mathrm{~B}$ ); a gradual decrease was observed from the dose of $86,46 \mathrm{~g}$ a.e. ha ${ }^{-1}$ glyphosate. Higher doses of the herbicide produced an important decrease in $g_{s}$; with the dose of $345,6 \mathrm{~g}$ a.e. $\mathrm{ha}^{-1}$ glyphosate, $\mathrm{g}_{\mathrm{s}}$ was $61 \%$ lower than in plants without treatment. This result indicates that in the dose of $43,2 \mathrm{~g}$ a.e. ha $^{-1}$ glyphosate, photosynthesis was not limited by stomatal closure.

The decrease in $A$ was accompanied by the increase in NPQ (Figure $1 C$ ), which is an important photoprotective mechanism that allows dissipating the excess of energy absorbed by the PSII light-harvesting complexes (AVILA, 2020).

The $F_{v} / F_{m}$ ratio was not affected by doses up to 172,8 g a.e. $\mathrm{ha}^{-1}$ glyphosate; however, the dose of 345,6 g a.e. $\mathrm{ha}^{-1}$ glyphosate produced a significant decrease of $21 \%$ against control (Figure 2A). The relationship $F_{v} / F_{m}$ is an indicator of PSII integrity. In healthy plants, $F_{v} / F_{m}$ is approximately 0,83 ; a decrease in the values of this variable indicates photoinhibition (WALTER et al., 2003).

The significant decrease in photosynthetic rate observed in doses of $172,8 \mathrm{~g}$ a.e. $\mathrm{ha}^{-1}$ and $345,6 \mathrm{~g}$ a.e. ha ${ }^{-1}$ glyphosate was accompanied by a decrease in Rubisco 
activity of $10 \%$ and $25 \%$ against control, respectively (Figure 2B).
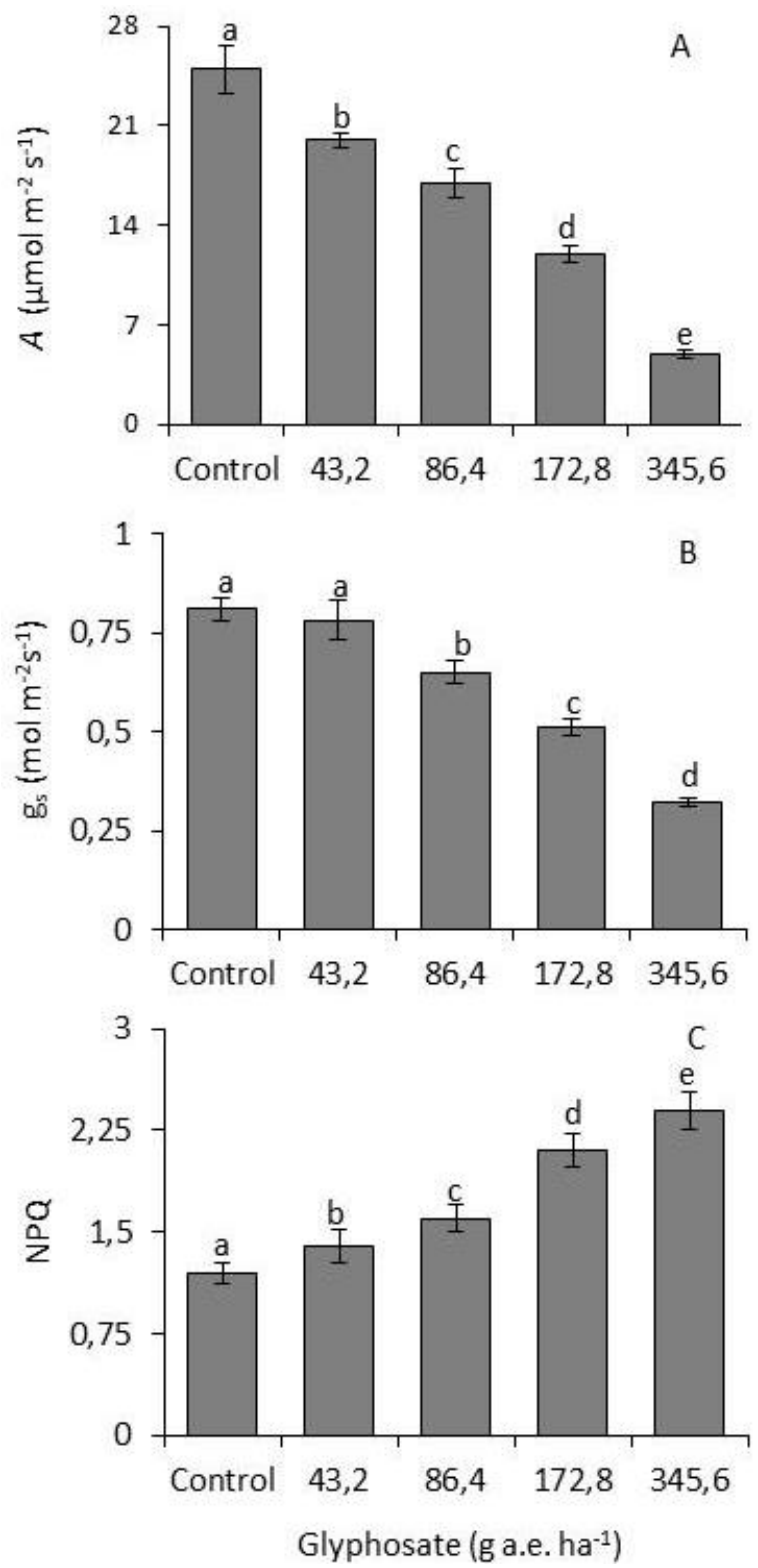

Figure 1. Carbon photosynthetic assimilation, $A(A)$, stomatal conductance, $g_{s}(B)$, and nonphotochemical quenching, NPQ (C) in Eucalyptus camaldulensis seedlings under simulated glyphosate drift. Vertical bars represent the standard deviation of the mean ( $n=10$ ). Different letters denote significant differences at level $\mathrm{P}<0.05$, according to Tukey test.

The effects of glyphosate on photosynthesis vary in different species and, within the same species, in different genotypes. In Solanum lycopersicum, doses of up to $30 \mathrm{mg}$ $\mathrm{kg}^{-1}$ glyphosate did not affect $A$ or the variables of chlorophyll a fluorescence. In this species, damages generated by glyphosate were associated with an increase in $g_{s}$ that produced a significant decrease in water use efficiency (SOARES et al., 2020). In Arachis hypogaea, 720 $\mathrm{g} \mathrm{ha}^{-1}$ glyphosate significantly reduced $A$, which is a nonstomatal effect because the intercellular concentration of $\mathrm{CO}_{2}$ remained constant (RADWAN \& FAYEZ, 2016). In Olea europaea, glyphosate did not affect net photosynthesis rates, $g_{s}$, or the $F_{v} / F_{m}$ ratio (CAÑERO et al., 2011).
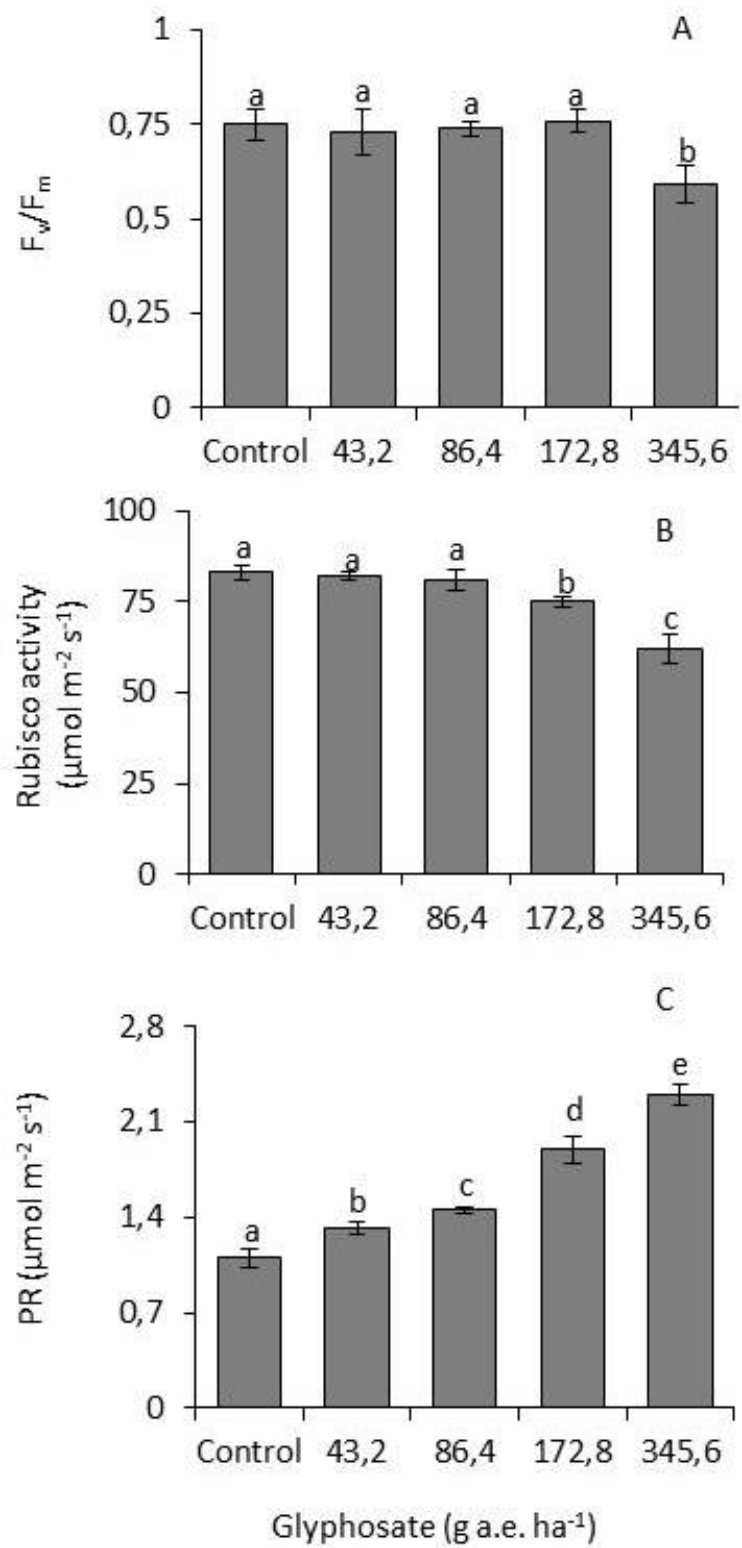

Figure 2. Maximum quantum yield of $P S I I, F_{v} / F_{m}(A)$, Rubisco activity (B), and photorespiration and PR (C) in Eucalyptus camaldulensis seedlings under simulated glyphosate drift. Vertical bars represent the standard deviation of the mean $(n=10)$. Different letters denote significant differences at level $\mathrm{P}<0.05$, according to Tukey test. 
Cerveira Junior et al. (2020) studied the response to glyphosate in Eucalyptus $x$ urograndis clones 1140 and GG100 seedlings. They observed that clone I140 was more sensitive to the herbicide than clone GG100, manifested in higher values of $A$ and $g_{s}$. However, there were no alterations in $\mathrm{F}_{\mathrm{v}} / \mathrm{F}_{\mathrm{m}}$ in the tested doses, which were within the range $0-180 \mathrm{~g}$ a.e. $\mathrm{ha}^{-1}$ glyphosate. These authors suggested that the inhibition in the growth of the Eucalyptus clones more sensitive to glyphosate is due to stomatal closure rather than to alterations in the photochemical stage of photosynthesis.

In E. $x$ urograndis clone $\mathrm{C} 219$, the $\mathrm{Fv}_{\mathrm{v}} / \mathrm{Fm}_{\mathrm{m}}$ ratio was not affected either by glyphosate in doses of 0-720 g a.e. ha-1 (CARVALHO et al. 2016). In E. grandis clones CLR383 and CLR384, a dose of $86,4 \mathrm{~g}$ a.e. $\mathrm{ha}^{-1}$ glyphosate produced a decrease of $27 \%$ and $32 \%$ in A against control, respectively, as well as degeneration of epidermal and parenchymatous cells (SANTOS et al., 2019).

All the tested doses of glyphosate increased photorespiration in E. camaldulensis (Figure 2C). This response agrees with the one observed in Arabidopsis thaliana, in which glyphosate increased guaiacol oxidase activity, one of the most important enzymes involved in photorespiration (DE FREITAS-SILVA et al., 2017). Vivancos et al. (2011) studied the proteome and redox profiling of glyphosate-sensitive and glyphosate-tolerant soybean cultivars. They obtained evidence of an increase in photorespiration in the glyphosate-tolerant cultivar in the presence of the herbicide.

Photorespiration could contribute to the protection of the photosynthetic apparatus, preventing photoinhibition up to the dose of $172,8 \mathrm{~g}$ a.e. $\mathrm{ha}^{-1}$ glyphosate, range in which $F_{v} / F_{m}$ remained constant. It has been demonstrated that this metabolic process consumes reducing equivalents, protecting the photosynthetic apparatus from photooxidation under stress conditions (LIMA NETO et al., 2017).

Membrane damage was estimated from electrolyte linkage, and it was evident from $172,8 \mathrm{~g}$ a.e. $\mathrm{ha}^{-1}$ glyphosate (Figure $3 \mathrm{~A}$ ). A similar trend was observed in the concentration of MDA, the product of lipid peroxidation that increased $80 \%$ against control in the highest dose of glyphosate (Figure 3B).

The maintenance of selective membrane permeability, observed in the doses of 43,2 g a.e. ha ${ }^{-1}$ and $86,4 \mathrm{~g}$ a.e. $\mathrm{ha}^{-1}$ glyphosate, coincided with the maintenance of low concentrations of $\mathrm{H}_{2} \mathrm{O}_{2}$ (Figure $3 \mathrm{C}$ ). The concentration of such ROS increased from $172,8 \mathrm{~g}$ a.e. ha ${ }^{-1}$ glyphosate, reaching its highest values in the dose of 345,6 $\mathrm{g}$ a.e. ha ${ }^{-1}$ glyphosate. High concentrations of ROS, such as $\mathrm{H}_{2} \mathrm{O}_{2}$, superoxide radical $\left(\mathrm{O}_{2}{ }^{\bullet-}\right)$, and hydroxyl radical $\left(\mathrm{HO}^{\bullet}\right)$, might be produced under stress conditions (CORPAS et al., 2017).
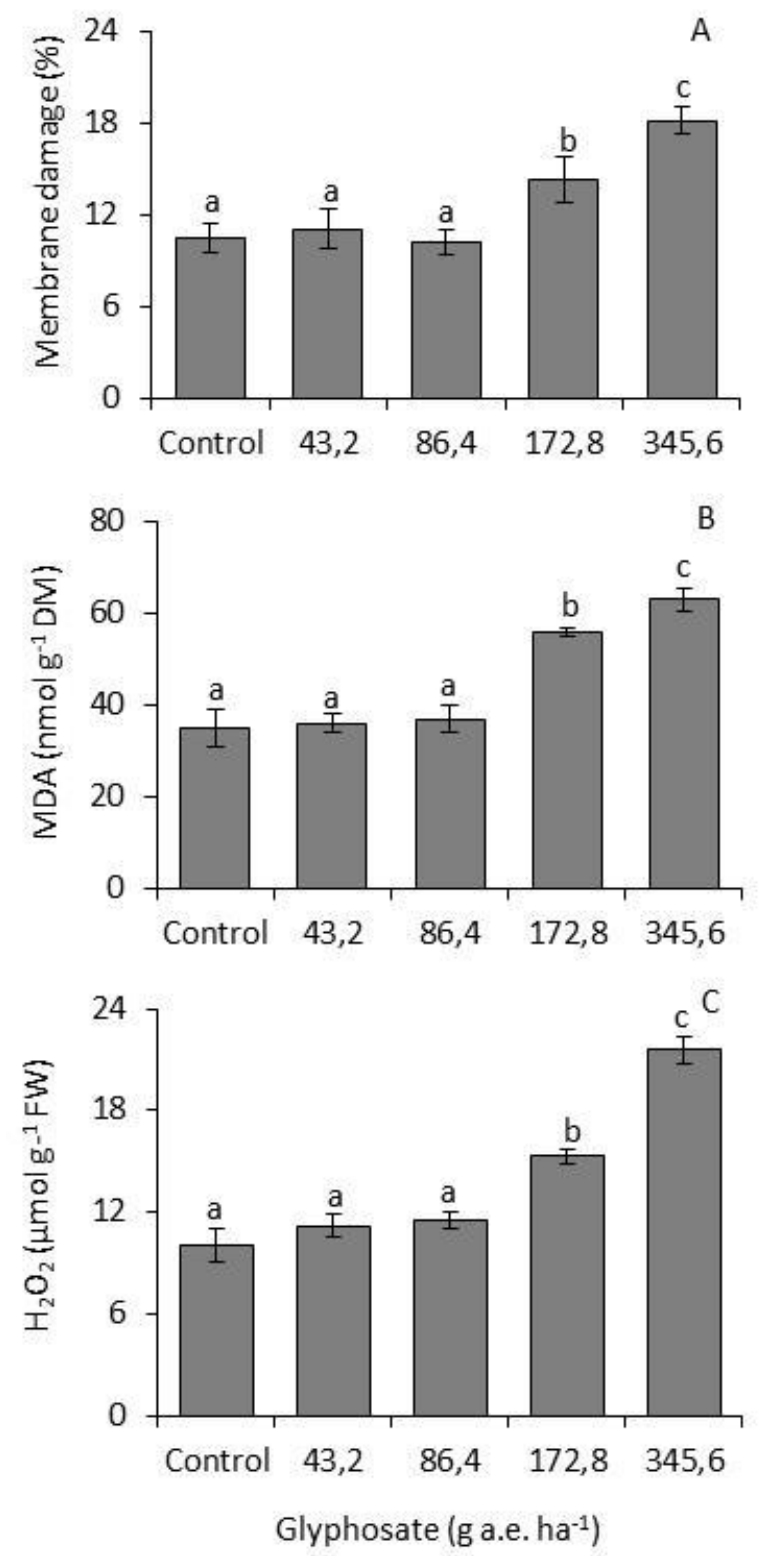

Figure 3. Membrane damage (A), malondialdehyde (MDA) content (B) and hydrogen peroxide $\left(\mathrm{H}_{2} \mathrm{O}_{2}\right)$ content (C), in leaves of Eucalyptus camaldulensis seedlings under simulated glyphosate drift. Vertical bars represent the standard deviation of the mean ( $n=10$ ). Different letters denote significant differences at level $P<0.05$, according to Tukey test.

In high concentrations, ROS might produce degradation of lipids, protein, and DNA, generating in extreme cases irreversible changes in metabolism (GOMES et al., 2014). Photorespiration is one of the main sources of $\mathrm{H}_{2} \mathrm{O}_{2}$ in leaves (ZIOTTI et al., 2019); in this 
work, the accumulation of $\mathrm{H}_{2} \mathrm{O}_{2}$ coincided with high photorespiratory rates.

In response to the stress generated by glyphosate, $E$. camaldulensis increased the activity of the antioxidant enzymes CAT, APX and SOD (Figure 4 A, B, C). However, the antioxidant system could not metabolize the produced $\mathrm{H}_{2} \mathrm{O}_{2}$ because the concentration of this ROS increased from the dose of $172,8 \mathrm{~g}$ a.e. ha-1 glyphosate. In the case of the dose of $345,6 \mathrm{~g}$ a.e. ha-1 glyphosate, the increase in the concentration of $\mathrm{H}_{2} \mathrm{O}_{2}$ could also be due to the increase in SOD activity. This enzyme acts on $\mathrm{O}_{2}{ }^{--}$ producing $\mathrm{H}_{2} \mathrm{O}_{2}$ and $\mathrm{O}_{2}$.
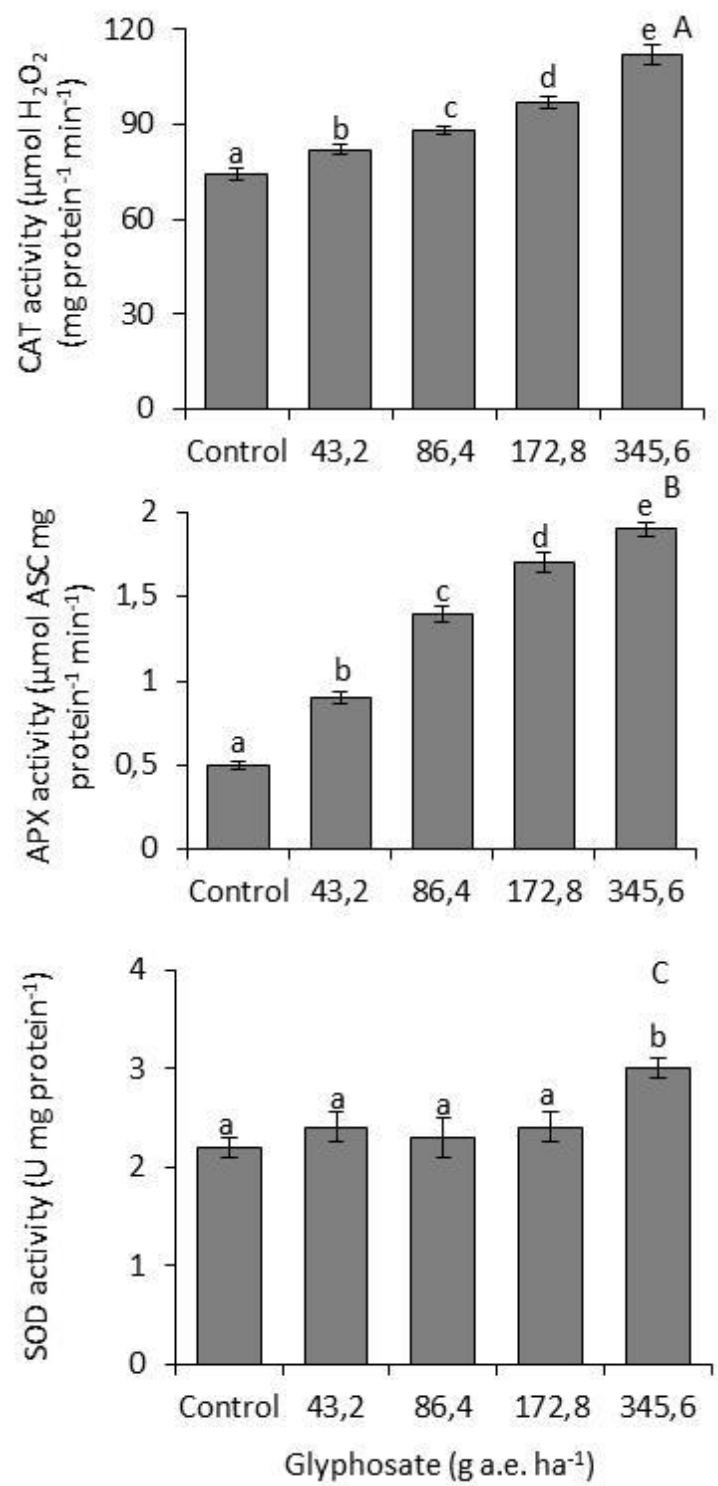

Figure 4. Catalase (CAT) activity (A), ascorbate peroxidase (APX) activity (B) and superoxide dismutase (SOD) activity (C) in leaves of Eucalyptus camaldulensis seedlings under simulated glyphosate drift. Vertical bars represent the standard deviation of the mean $(n=10)$.
Different letters denote significant differences at level $P<0.05$, according to Tukey test.

The oxidative stress generated by glyphosate on $E$. camaldulensis was similar to the response observed in Salix miyabeana (GOMES et al., 2017) and Solanum lycopersicum (SOARES et al., 2019). In these species, glyphosate increased the concentration of $\mathrm{H}_{2} \mathrm{O}_{2}$ and, despite the increase of CAT and APX activities, produced lipid peroxidation. In Arabidopsis thaliana, glyphosate increased CAT and APX activities, inhibiting SOD activity, whereas the concentration of $\mathrm{H}_{2} \mathrm{O}_{2}$ remained constant (DE FREITAS SILVA et al., 2017). There was not oxidative stress in glyphosate-sensitive soybean cultivars, as the plants presented low concentrations of MDA (MOLDES et al., 2008).

\section{CONCLUSIONS}

We concluded that glyphosate decreases the assimilatory rate of $\mathrm{CO}_{2}$ in $E$. camaldulensis. This response is mainly due to stomatal and non-stomatal effects. Rubisco activity, increased photorespiration, and photoinhibition stand out among non-stomatal effects. The increase in the antioxidant system activity is insufficient to compensate for the production of $\mathrm{H}_{2} \mathrm{O}_{2}$ in photorespiration, which damages the photosynthetic apparatus.

\section{REFERENCES}

ALEXIEVA, V. et al. The effect of drought and ultraviolet radiation on growth and stress markers in pea and wheat. Plant, Cell and Environment, v.24, n.12, p.1337-1344, 2001.

AVILA, R.T. et al. Starch accumulation does not lead to feedback photosynthetic downregulation in girdled coffee branches under varying source-to-sink ratios. Trees, v.34, n.1, p.1-16, 2020.

BRADFORD, M.M. A rapid and sensitive method for the quantification of microgram quantities of protein utilizing the principle of protein-dye binding. Analytical Biochemistry, v.722, n.1-2, p. 248-254, 1976

CAKMAK, I.; HORST, W.J. Effect of aluminium on lipid peroxidation, superoxide dismutase, catalase, and peroxidase activities in root tips of soybean (Glycine max). Physiologia Plantarum, v.83, n.3, p.463-468, 1991.

CAÑERO, A.I. et al. Effect of the herbicides terbuthylazine and glyphosate on photosystem II photochemistry of young olive (Olea europaea) plants. Journal of Agricultural Food and Chemistry, v.59, n.10, p.5528-5534, 2011. 
CARVALHO, L.B. et al. Content and fluorescence of chlorophyll in eucalypt exposed to glyphosate. Communications in Plant Science, v.6, n.1-2, p.7-11, 2016.

CERVEIRA JUNIOR, W.R. et al. Growth, morphological, metabolic and photosynthetic responses of clones of eucalyptus to glyphosate. Forest Ecology and Management, v.470-471, p.118218, 2020.

CORPAS, F.J. et al. Plant peroxisomes: a nitro-oxidative cocktail. Redox Biology, v.11, p.535-542, 2017.

CRUZ, A.R. et al. Physiological, morphological and biochemical studies of glyphosate tolerance in Mexican Cologania (Cologania broussonetii (Balb.) DC.). Plant Physiology and Biochemistry, v.98, p.72-80, 2016.

DE FREITAS-SILVA, L. et al. Glyphosate-induced oxidative stress in Arabidopsis thaliana affecting peroxisomal metabolism and triggers activity in the oxidative phase of the pentose phosphate pathway (OxPPP) involved in NADPH generation. Journal of Plant Physiology, v.218, p.196-205, 2017.

DE MARÍA, N. et al. New insights on glyphosate mode of action in nodular metabolism: Role of shikimate accumulation. Journal of Agricultural Food and Chemistry, v.54, n.7, p.2621-2628, 2006.

HAVIR, E.A.; MCHALE, N.A. Biochemical and developmental characterization of multiple forms of catalase in tobacco leaves. Plant Physiology, v.84, n.2, p.450-455, 1987.

GIANNOPOLITIS, N.; RIES, S.K. Superoxide dismutase. I. Occurrence in higher plants. Plant Physiology, v.59, n.2, p.309314, 1977.

GOMES, M.P. et al. Alteration of plant physiology by glyphosate and its by-product aminomethylphosphonic acid: an overview. Journal of Experimental Botany, v.65, n.17, p.4691-4703, 2014.

GOMES, M.P. et al. Differential effects of glyphosate and aminomethylphosphonic acid (AMPA) on photosynthesis and chlorophyll metabolism in willow plants. Pesticide Biochemistry and Physiology, v.13, p.65-70, 2016.

GOMES, M.P. et al. Glyphosate-dependent inhibition of photosynthesis in willow. Frontiers in Plant Science, v.65, 2017.

LIMA NETO, M.C. et al. Cyclic electron flow, NPQ and photorespiration are crucial for the establishment of young plants of Ricinus communis and Jatropha curcas exposed to drought. Plant Biology, v.19, n.4, p.650-659, 2017.

MAROLI, A.S. et al. Metabolic profiling and enzyme analyses indicate a potential role of antioxidant systems in complementing glyphosate resistance in an Amaranthus palmeri Biotype. Journal of Agricultural Food and Chemistry, v.63, n.41, p.9199-9209, 2015.

MAXWELL, K.; JOHNSON, G.N. Chlorophyll fluorescence-a practical guide. Journal of Experimental Botany, v.51, n.345, p.659-668, 2000.
MITEVA, L.P. et al. Alterations in glutathione pool and some related enzymes in leaves and roots of pea plants treated with the herbicide glyphosate. Russian Journal of Plant Physiology, v.57, n.1, p.131-136, 2010.

MOLDES, C.A. et al. Biochemical responses of glyphosate resistant and susceptible soybean plants exposed to glyphosate. Acta Physiologiae Plantarum, v.30, p.469-479, 2008.

NAKANO, Y.; ASADA, K. Hydrogen peroxide is scavenged by ascorbate-specific peroxidase in spinach chloroplasts. Plant and Cell Physiology, v.22, n.5, p.867-880, 1981.

RADWAN, D.E.M.; FAYEZ, K.A. Photosynthesis, antioxidant status and gas-exchange are altered by glyphosate application in peanut leaves. Photosynthetica, v.5, p.307-316, 2016.

REID, C.D. et al. Comparison of spectrophotometric and radioisotopic methods for the assay of Rubisco in ozone-treated plants. Physiologiae Plantarum, v.101, p.398-404, 1997.

SANTOS JUNIOR, A. et al. Glyphosate drift in eucalyptus plants. Planta Daninha, v.33, n.3, p.615-621, 2015.

SANTOS, S.A. et al. Differential tolerance of clones of Eucalyptus grandis exposed to drift of the herbicides carfentrazone-ethyl and glyphosate. Planta Daninha, v.33, e019175977, 2019.

SCHREIBER, U. et al. Chlorophyll fluorescence as a nonintrusive indicator for rapid assessment of in vivo photosynthesis. Ecophysiology of photosynthesis, v.100, p.49-70, 1994.

SERRA, A.A. et al. Low environmentally relevant levels of bioactive xenobiotics and associated degradation products cause cryptic perturbations of metabolism and molecular stress responses in Arabidopsis thaliana. Journal of Experimental Botany, v.64, n.10, p.2753-2766, 2013.

SILVA, E.N. et al. Photosynthesis impairment and oxidative stress in Jatropha curcas exposed to drought are partially dependent on decreased catalase activity. Acta Physiologiae Plantarum, v.41, p.1-12, 2019.

SOARES, C. et al. Is soil contamination by a glyphosate commercial formulation truly harmless to non-target plants? Evaluation of oxidative damage and antioxidant responses in tomato. Environmental Pollution, v.247, p.256-265, 2019.

SOARES, C. et al. Glyphosate-dependent effects on photosynthesis of Solanum lycopersicum L.- An ecophysiological, ultrastructural and molecular approach. Journal of Hazardous Materials, v.398, e122871, 2020.

SOUSA, C.P. et al. Photosynthesis of soybean under the action of a photosystem II-inhibiting herbicide. Acta Physiologiae Plantarum, v.36, p.3051-3062, 2014.

TUFFI SANTOS, L.D. et al. Morphological responses of different eucalypt clones submitted to glyphosate drift. Environmental and Experimental Botany, v.59, n.1, p.1-20, 2007.

TUFFI SANTOS, L.D. et al. Glyphosate reduces urediniospore development and Puccinia psidii disease severity on Eucalyptus grandis. Pest Management Science, v.67, p.876-880, 2011. 
VALENTINI, R. et al. In situ estimation of net $\mathrm{CO}_{2}$ assimilation, photosynthetic electron flow and photorespiration in Turkey oak (Q. cerris L.) leaves: diurnal cycles under different levels of water supply. Plant Cell and Environment, v.18, n.6, p.631-640, 1995.

VIVANCOS, P.D. et al. Perturbations of amino acid metabolism associated with glyphosate-dependent inhibition of shikimic acid metabolism affect cellular redox homeostasis and alter the abundance of proteins involved in photosynthesis and photorespiration. Plant Physiology, v.157, n.1, p.256-268, 2011.

WALTER, A. et al. Transitions in photosynthetic parameters of midvein and interveinal regions of leaves and their importance during leaf growth and development. Plant Biology, v.6, n.2, p.184-191, 2003.

ZIOTTI, A.B.S. et al. Photorespiration is crucial for salinity acclimation in castor bean. Environmental and Experimental Botany, v.167, e103845, 2019.

Recebido em 07-10-2020 Aceito em 04-11-2020 